\title{
Green abalone, Haliotis fulgens infected with the agent of withering syndrome do not express disease signs under a temperature regime permissive for red abalone, Haliotis rufescens
}

\author{
James D. Moore • Christy I. Juhasz • \\ Thea T. Robbins $\cdot$ L. Ignacio Vilchis
}

Received: 4 March 2009/Accepted: 6 July 2009/Published online: 23 July 2009

(c) The Author(s) 2009. This article is published with open access at Springerlink.com

\begin{abstract}
All California abalone species have been shown to be susceptible to infection with the bacterial agent of abalone withering syndrome (WS), although expression of signs of the disease may vary between species and with environmental conditions. We examined thermal modulation of WS expression in green abalone Haliotis fulgens at temperatures mimicking El Niño $\left(18.0^{\circ} \mathrm{C}\right)$ and La Niña $\left(14.2^{\circ} \mathrm{C}\right)$ events in southern California. In contrast to results obtained from previous experiments with red abalone, $H$. rufescens, the higher temperature did not result in higher infection intensities of the causative agent of the disease nor increase in clinical signs of disease. These results demonstrate clear differences in thermal regulation of disease expression between abalone species, and provide further data suggesting that
\end{abstract}

Communicated by T. Reusch.

J. D. Moore $(\bowtie) \cdot$ T. T. Robbins

Fisheries Branch, California Department of Fish and Game, P. O. Box 247, Bodega Bay, CA, USA

e-mail: jdmoore@dfg.ca.gov; jimmoore@ucdavis.edu

J. D. Moore · C. I. Juhasz

Bodega Marine Laboratory, University of California at Davis, P. O. Box 247, Bodega Bay, CA, USA

J. D. Moore

Department of Medicine and Epidemiology,

School of Veterinary Medicine, University of California,

One Shields Avenue, Davis, CA, USA

L. I. Vilchis

Scripps Institution of Oceanography, University of California,

La Jolla, San Diego, CA, USA green abalone should be a target species of recovery efforts in southern California, where WS is endemic.

\section{Introduction}

Five abalone species present in the southern California bight have severely depleted populations as a result of 40 50 years of overfishing followed by two decades of disease. In 1997 all recreational and commercial abalone fisheries in southern and central California were closed, and in 2005 the California Fish and Game Commission adopted a comprehensive Abalone Recovery and Management Plan as a framework for restoration of southern California populations and management of the northern California red abalone recreational fishery (California Department of Fish and Game 2005). The Plan includes species-specific recommendations for recovery of pink Haliotis corrugata, green $H$. fulgens, white $H$. sorenseni, red $H$. rufescens, and black $H$. cracherodii abalone. The green abalone occupies the warmest subtidal habitat, occurring in shallow waters from Point Conception, California, USA to southern Baja California, Mexico. Green abalone populations in both Mexico and California have been steadily declining for decades, and $H$. fulgens was listed in the United States as a federal Species of Concern (a step toward federal endangered species status) in 2004 (Federal Register 2004).

Withering syndrome (WS) is a chronic wasting disease of multiple California abalone species caused by infection with the bacterium Candidatus Xenohaliotis californiensis (Friedman et al. 2000; Moore et al. 2001, 2002), also referred to as withering syndrome-associated Rickettsialeslike prokaryote, or WS-RLP. It was first observed in Channel Islands black abalone in the mid-1980s (Haaker et al. 1992; Lafferty and Kuris 1993), and has resulted in 
such dramatic declines that the species was listed under the federal Endangered Species Act in 2009 (Federal Register 2009). Although red abalone are clearly also susceptible to the disease, the extent to which it is influencing pink, white and green abalone populations remains unclear.

Thermal modulation of withering syndrome is welldocumented in farmed red abalone. Exposure of animals infected with Candidatus Xenohaliotis californiensis to $18.5^{\circ} \mathrm{C}$ water for 220 days resulted in expression of WS clinical signs and $33 \%$ mortality, while no control animals maintained at $14.7^{\circ} \mathrm{C}$ died and few exhibited WS signs (Moore et al. 2000). Similarly, Braid et al. (2005) conducted a 447-day study on red abalone including conditions of high $\left(18.7^{\circ} \mathrm{C}\right)$ versus low $\left(12.3^{\circ} \mathrm{C}\right)$ temperature, high versus low food supply, and exposure versus no exposure to Candidatus Xenohaliotis californiensis in all combinations. Mortality was associated with both starvation and WS, and WS signs were much more severe among the Candidatus Xenohaliotis californiensis-exposed animals in warm versus cold water. This was also the first study on WS that included control groups not infected with Candidatus Xenohaliotis californiensis, and demonstrated that warm water stress alone is not responsible for the clinical signs observed (the Candidatus Xenohaliotis californiensis-free abalone that were held in warm water and provided food remained healthy). Vilchis et al. (2005) conducted an additional long-term study investigating the effects of food quantity, food quality and temperature on both red and green abalone. While red abalone showed high susceptibility to WS at elevated temperature, green abalone did not; in fact green abalone showed exceedingly low levels of Candidatus Xenohaliotis californiensis infection in all treatments. This provided evidence that green abalone may be more resistant to WS than red abalone held under similar conditions, including those of a southern California El Niño event. However, the experiments with the two species were conducted sequentially over 2 years and it is possible that the green abalone received less exposure to Candidatus Xenohaliotis californiensis than did the red abalone. Del Álvarez et al. (2002) reported that green abalone can be susceptible to WS; individuals bearing Candidatus Xenohaliotis californiensis infections and showing clinical signs of WS were observed among green abalone populations during the 1997-1998 El Niño event at three major fishery sites in Baja California, Mexico, near the southern border of the species' range. The temperature regime was not reported, although it was undoubtedly warmer than southern California (Ponce-Díaz et al. 2004). Similarly, Garcia-Esquivel et al. (2007) reported that green abalone held at $25^{\circ} \mathrm{C}$ and fed an abundant synthetic diet for 6 months experienced more clinical signs of WS and higher mortality than those held at $20^{\circ} \mathrm{C}$. Histological examination of the abalone with
WS signs indicated high levels of Candidatus Xenohaliotis californiensis and WS-related tissue alterations, although no comparison with healthy abalone was made.

Our objectives were to investigate the health and survival of Candidatus Xenohaliotis californiensis-infected green abalone under southern California El Niño conditions that are known to enhance disease expression in red abalone. We thereby conducted a differential temperature experiment with green abalone similar to those previously undertaken with red abalone. This study differs from a previous study on green abalone (Vilchis et al. 2005) in that all abalone were held under conditions that were demonstrated to include exposure to Candidatus Xenohaliotis californiensis.

\section{Materials and methods}

Animals and experimental setup

Farmed adult green abalone $(N=\sim 110)$, tagged by inserting a coded stainless steel washer on stainless steel wire through the first and second most recently formed respiratory pores, were acquired from Scripps Institution of Oceanography in October 2002 and transferred to the Pathogen Containment Facility at the Bodega Marine Laboratory. All effluent from this facility is treated with chlorine $(10 \mathrm{mg} / \mathrm{L})$ for $2 \mathrm{~h}$ and dechlorinated with sulfur dioxide before release. Eleven of the abalone were sampled by histology (below) upon arrival and five were found to be positive for Candidatus Xenohaliotis californiensis. The remaining animals were randomly distributed in equal numbers into twelve, 9-L volume tanks receiving ambient (approximately $14^{\circ} \mathrm{C}$ ) flowing, aerated seawater until October 2003. All tanks were supplied with kelp (Macrocystis pyrifera) two to three times per month during this period and throughout the experiment. Tests for the presence of Candidatus Xenohaliotis californiensis in tissue (histology) and/or feces (polymerase chain reaction assay, Andree et al. 2000) indicated that infected abalone were present in every tank. The 12 tanks were randomly assigned to receive either cool water $\left(14.2^{\circ} \mathrm{C}\right)$ or warm water $\left(18.0^{\circ} \mathrm{C}\right)$. The abalone were $98.9 \pm 6.0 \mathrm{~mm}($ mean $\pm \mathrm{SD})$ in shell length at the beginning of the study, which began on 16 October 2003, following elevation of the temperature on the warm water group over several days. The study was terminated 377 days later.

Candidatus Xenohaliotis californiensis infection intensity and indicators of health

Tissue sampling and histological processing were performed as previously described (Moore et al. 2001). 
Davidson's-fixed (Shaw and Battle 1957), hematoxylin and eosin-stained $5 \mu \mathrm{m}$ paraffin tissue sections containing postesophagus, digestive gland, foot muscle, kidney and gonad were prepared from animals that died during the experiment and all survivors upon termination. Slides were encoded to prevent bias during assessment. Candidatus Xenohaliotis californiensis burdens in the postesophagus and digestive gland were quantified based on the average number of inclusions per $200 \times$ magnification field of view: absent $=(0), 1-10=(1), 11-100=(2)$, or greater than $100=(3)$. Four disease signs of WS were assessed using integral scales from 0 to 3 (Moore et al. 2001). For all four parameters $(0)$ represented a normal healthy appearance. For body shrinkage, (1), (2) and (3) represented slight, moderate and severe shrinkage of the body mass, respectively; for digestive gland transport duct area and digestive gland atrophy, (1), (2) and (3) denote 5-10\%, 11-25\%, and greater than $25 \%$ of the digestive gland being comprised of transport duct epithelia or connective tissue, respectively. Foot degeneration scores of (1), (2) and (3) denote muscle fibers comprising $76-90 \%, 51-75 \%$ and less than $50 \%$ of the foot muscle, respectively. A condition index, $\mathrm{CI}=$ total weight $(\mathrm{g}) /[\text { shell length }(\mathrm{cm})]^{3}$, was also used to assess body shrinkage. The kidney coccidian parasite Pseudoklossia haliotis (Friedman et al. 1995) was noted as being present or absent. Each abalone was also scored as being male, female, or of indeterminable sex. The food consumption rate in each tank was measured during the 24-h period preceding termination by measuring initial and final weights of kelp placed in each tank, and was expressed as a proportion of combined body weights (=total weight - shell weight) of the animals in each tank.

\section{Data analysis}

In our experimental design, the individual abalone was designated the experimental unit, using a fully nested design with six replicate tanks within each of two temperatures. A general linear model (Systat 11) was used to examine the effects of temperature and tank within temperature. Data categorized on a zero-to-three scale were normalized by square root transformation $x^{\prime}=\sqrt{(x+3 / 8)}$ prior to statistical analysis. Data from animals that died during the experiment were included in all data sets except weight gain among survivors. Fisher's exact test using data from combined replicate tanks for each temperature was used to compare the two groups with respect to the proportions that died, were infected with Candidatus Xenohaliotis californiensis, exhibited gonadal development, or were infected with the kidney coccidian parasite Pseudoklossia haliotis. Food consumption data were compared with a $t$ test between the six tank values for each temperature regime.

\section{Results}

The size, shape and tissue distribution of Candidatus Xenohaliotis californiensis inclusions (Fig. 1) in both cool and warm water treatment groups were similar to those previously reported in multiple species of California abalone. Data sets from this experiment and results of comparisons between the cool and warm water groups are shown in Table 1. All indicators of survivorship and body condition, including cumulative mortality, body shrinkage, weight gain, condition index and gonadal development, showed that most abalone remained relatively healthy throughout the experiment in both water treatments (Table 1). There were no significant effects of temperature $(P$ values shown in Table 1$)$ or tank within temperature (all $P$ values $>0.10$, not shown) on the parameters measured. On average, one of every six abalone died during the 377day experiment in both water treatments. Foot muscle degeneration scores were very low and similar for both groups, and food consumption rates on the day before termination were indistinguishable. Corresponding with these health indicators were very low and insignificantly different Candidatus Xenohaliotis californiensis infection prevalence and intensities in the two groups. The prevalence of Candidatus Xenohaliotis californiensis-positive individuals among the six in each tank ranged from $1 / 6$ to $5 / 6$ in cool water and $0 / 6$ to $4 / 6$ in warm water. The one tank with zero prevalence had tested positive by PCR at the beginning of the experiment; apparently no infections among the individuals in that tank advanced to the stage of being detectable by histology. A coccidian parasite known to infect kidney tissue of several California abalone species

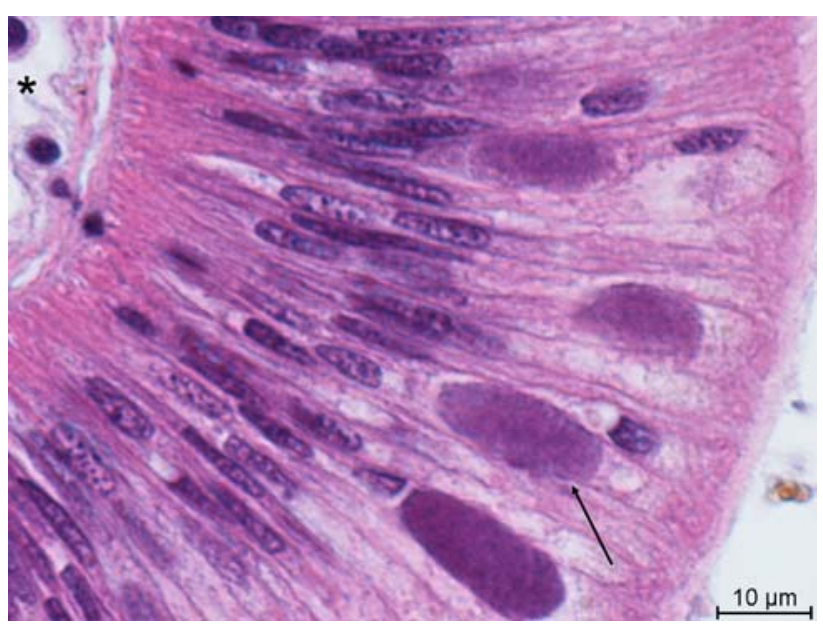

Fig. 1 Postesophagus of green abalone infected with the agent of withering syndrome, Candidatus Xenohaliotis californiensis. Several hemocytes within the subepithelial connective tissue are visible at upper left (asterisk). Basophilic Candidatus Xenohaliotis californiensis inclusions (arrow) occur within the epithelium. Lumen of the postesophagus is at lower right 
Table 1 Exposure temperatures, Candidatus Xenohaliotis californiensis infection intensities, withering syndrome signs and other symbionts in green abalone held in cool or warm water for 377 days
Data shown are mean (standard error) of treatment groups, $P$ values are for statistical tests described in the "Materials and methods"

\begin{tabular}{lccc}
\hline & \multicolumn{2}{l}{ Thermal regime } & $\begin{array}{l}\text { Significance } \\
\text { of test }(P)\end{array}$ \\
\cline { 2 - 4 } & La Niña & El Niño & \\
\hline Temperature $\left({ }^{\circ} \mathrm{C}\right)$ & $14.2(0.1)$ & $18.0(0.1)$ & $<0.001$ \\
\% Positive for Candidatus Xenohaliotis californiensis & $45(8.9)$ & $30(9.8)$ & 0.44 \\
Candidatus Xenohaliotis californiensis infection & $0.54(0.14)$ & $0.47(0.14)$ & 0.52 \\
$\quad$ intensity in postesophagus & & & \\
Candidatus Xenohaliotis californiensis infection & $0.07(0.05)$ & $0.19(0.10)$ & 0.4 \\
$\quad$ intensity in digestive gland & & & \\
WS signs & & & 1 \\
\% mortality & $16.7(4.5)$ & $16.7(7.5)$ & 0.59 \\
Body shrinkage & $0.15(0.06)$ & $0.23(0.11)$ & 0.75 \\
Weight gain among survivors $(\mathrm{g})$ & $17.5(2.9)$ & $14.8(3.3)$ & 0.75 \\
Condition index $\left(\mathrm{g} / \mathrm{cm}^{3}\right)$ & $0.162(0.003)$ & $0.160(0.003)$ & 0.12 \\
Digestive gland transport duct area & $0.07(0.05)$ & $0.28(0.12)$ & 0.19 \\
Digestive gland atrophy & $0.10(0.05)$ & $0.28(0.11)$ & 0.37 \\
Foot muscle degeneration & $0.13(0.08)$ & $0.33(0.16)$ & 0.25 \\
Food consumption $(\mathrm{g} / \mathrm{g}$ body weight) & $0.12(0.01)$ & $0.14(0.01)$ & 0.8 \\
$\%$ Exhibiting gonadal development & $48.3(0.1)$ & $53.1(0.1)$ & \\
Other symbionts & $35(4.5)$ & $47(16)$ & 0.61 \\
\% With kidney coccidia & & & \\
\hline
\end{tabular}

was prevalent at similar frequencies in both treatment groups.

\section{Discussion}

Exposure of Candidatus Xenohaliotis californiensis-infected green abalone to water temperatures similar to those of a southern California El Niño event did not induce an increase in Candidatus Xenohaliotis californiensis burdens and attendant signs of WS. This is in contrast to previous studies with red abalone conducted at similar temperatures. Our elevated temperature of $18.0^{\circ} \mathrm{C}$ is similar to a yearlong mean temperature of $18.3^{\circ} \mathrm{C}$ recorded during the 1997-1998 El Niño event at a location that historically supported green abalone (Church Rock at the east end of
Catalina Island, 4.6 M depth, 6/1/97-5/31/98). A summary of studies on thermal modulation of WS in black, red and green abalone is shown in Table 2. Our results agree with the conclusions of Vilchis et al. (2005) and extend their findings by demonstrating that green abalone definitively exposed to Candidatus Xenohaliotis californiensis do not express the disease under southern California El Niño conditions.

The green abalone is a warmer water species than black abalone or red abalone (California Department of Fish and Game 2001) and green abalone in more southerly locations routinely experience much higher temperatures than occur off southern California. Díaz et al. (2006) reported that a 'preferred' temperature (in a gradient) for green abalone was $25.4^{\circ} \mathrm{C}$, while a critical thermal maximum (temperature at which individuals lose attachment) was $33.6^{\circ} \mathrm{C}$.

Table 2 Temperatures and WS-related responses in published studies investigating the effects of temperature on development of withering syndrome in three species of abalone

\begin{tabular}{|c|c|c|c|c|c|c|c|}
\hline \multirow[t]{2}{*}{ Species } & \multicolumn{4}{|c|}{ Mean temperature $\left({ }^{\circ} \mathrm{C}\right)$} & \multirow{2}{*}{$\begin{array}{l}\text { Candidatus Xenohaliotis } \\
\text { californiensis } \\
\text { Intensity increase } \\
\text { with temperature? }\end{array}$} & \multicolumn{2}{|l|}{ WS signs } \\
\hline & Low & Intermediate & High & \# Days & & $\begin{array}{l}\text { Increase with } \\
\text { temperature? }\end{array}$ & Reference \\
\hline H. cracherodii & 13 & & 20 & 280 & Not reported & Yes & Friedman et al. (1997) \\
\hline H. rufescens & 14.7 & & 18.5 & 220 & Yes & Yes & Moore et al. (2000) \\
\hline H. rufescens & 12.3 & & 18.7 & 447 & Yes & Yes & Braid et al. (2005) \\
\hline H. rufescens & 13.5 & 16.0 & 18.4 & 347 & Yes & Yes & Vilchis et al. (2005) \\
\hline H. fulgens & 14.0 & 16.7 & 19.6 & 345 & No & No & Vilchis et al. (2005) \\
\hline H. fulgens & 14.2 & & 18.0 & 377 & No & No & This study \\
\hline
\end{tabular}


A previous study with red abalone using the same methods reported 18.8 and $27.5^{\circ} \mathrm{C}$ for preferred and critical maximum temperatures, respectively Díaz et al. (2000). These results, in combination with observations of WS in farmed Mexican green abalone at temperatures of approximately $25^{\circ} \mathrm{C}$, suggest a hypothesis that the temperature at which clinical WS is induced in Candidatus Xenohaliotis californiensis-infected abalone is related to the species' normal temperature optimum.

In California, a rapid rise and dramatic decline in commercial green abalone landings from 1964 to 1984 was one segment of a species-by-species serial depletion of abalone populations (Karpov et al. 2000). The green abalone, along with red, pink, white and to some extent black abalone, were significantly depleted before the arrival of WS in the Channel Islands in 1985. The results of our study suggest that WS may not be of critical importance in the failure of green abalone to recover in southern California following the collapse and closure of the fishery. Morales-Bojórquez et al. (2008) also concluded that dramatic declines in green abalone abundance in Baja California were due primarily to overfishing, although the intensive fishery may have masked more subtle effects of disease.

Vilchis et al. (2005) emphasized that the difference in responses of red abalone versus green abalone to southern California El Niño conditions should be incorporated into fisheries management and restoration efforts. They also point out that the traditional assumption in fishery management of a constant environment is inappropriate, particularly for slow-growing species such as abalone in a region with inter-annual and decadal fluctuations such as the southern California bight. We echo these recommendations, emphasizing that fisheries management and restoration need to consider species-specific responses to climate variability and consequent disease, as well as the predicted impacts of localized ocean warming associated with global climate change.

In conclusion, thermal modulation of WS differs between abalone species, with green abalone relatively resistant to disease expression under southern California El Niño conditions. This difference between species suggests that elevated temperature does not cause WS simply by increasing the rate of WS-RLP replication; host factors contribute to disease susceptibility or resistance. Recovery efforts for southern California abalone should focus on species able to tolerate the presence of endemic diseases.

Acknowledgments The Catalina Conservancy Divers provided temperature data from Church Rock, Catalina Island. Elizabeth Vu assisted with the care and maintenance of the animals. Calvin Chun assisted with statistical analyses. Supported in part by the California Department of Fish and Game. Contribution number 2466, Bodega Marine Laboratory.
Open Access This article is distributed under the terms of the Creative Commons Attribution Noncommercial License which permits any noncommercial use, distribution, and reproduction in any medium, provided the original author(s) and source are credited.

\section{References}

Andree KB, Friedman CS, Moore JD, Hedrick RP (2000) A polymerase chain reaction for detection of genomic DNA of a Rickettsiales-like prokaryote associated with withering syndrome in black abalone (Haliotis cracherodii). J Shellfish Res 19:213-218

Braid BA, Moore JD, Robbins TT, Hedrick RP, Tjeerdema RS, Friedman CS (2005) Health and survival of red abalone, Haliotis rufescens, under varying temperature, food supply, and exposure to the agent of withering syndrome. J Invertebr Pathol 89:219 231

California Department of Fish and Game (2001) California's living marine resources: a status report. California Department of Fish and Game, Sacramento

California Department of Fish and Game (2005) Abalone recovery and management plan. California Department of Fish and Game, Sacramento

Del Álvarez C, Tinajero MC, Cáceres-Martínez J, Gonzáles-Avilés JG (2002) Histopathological evaluation of the yellow abalone Haliotis corrugata and the blue abalone Haliotis fulgens from Baja California, Mexico. J Shellfish Res 21:825-830

Díaz F, del Río-Portílla MA, Sierra E, Aguilar M, Re-Araujo AD (2000) Preferred temperature and critical thermal maxima of red abalone Haliotis rufescens. J Therm Biol 25:7-261

Díaz F, Re AD, Medina Z, Re G, Valdez G, Valenzuela F (2006) Thermal preference and tolerance of green abalone Haliotis fulgens (Philippi, 1845) and pink abalone Haliotis corrugata (Gray, 1828). Aquac Res 37:877-884

Federal Register (2004) Identifying 45 species of concern. 69(73): 19977

Federal Register (2009) Endangered and threatened wildlife and plants: endangered status for black abalone. 74(9):1937-1946

Friedman CS, Gardner GR, Hedrick RP, Stephenson M, Cawthorn RJ, Upton SJ (1995) Pseudoklossia haliotis sp. n. (Apicomplexa) from the kidney of California abalone, Haliotis spp. (Mollusca). J Invertebr Pathol 66:33-38

Friedman CS, Thomson M, Chun C, Haaker PL, Hedrick RP (1997) Withering syndrome of the black abalone, Haliotis cracherodii (Leach): water temperature, food availability, and parasites as possible causes. J Shellfish Res 16:403-411

Friedman CS, Andree KB, Beauchamp K, Moore JD, Robbins TT, Shields JD, Hedrick RP (2000) "Candidatus Xenohaliotis californiensis", a newly described pathogen of abalone Haliotis spp., along the west coast of North America. Int J Syst Evol Microbiol 50:847-855

Garcia-Esquivel Z, Montes-Magallón S, Gonzáles-Gómez MA (2007) Effect of temperature and photoperiod on the growth, feed consumption, and biochemical content of juvenile green abalone, Haliotis fulgens, fed on a balanced diet. Aquaculture 262:129141

Haaker PL, Parker DO, Togstad H, Richards DV, Davis GE, Friedman CS (1992) Mass mortality and withering syndrome in black abalone, Haliotis cracherodii, in California. In: Shepherd SA, Tegner MJ, Gusman del Proo SA (eds) Abalone of the world: biology, fisheries and culture. Proceedings of the first international symposium on abalone. University Press, Cambridge, pp 214-224 
Karpov KA, Haaker PL, Taniguchi IK, Rogers-Bennett L (2000) Serial depletion and the collapse of the California abalone (Haliotis spp.) fishery. In: Campbell W (ed) Workshop on rebuilding abalone stocks in British Columbia. Can Spec Publ Fish Aquat Sci 130:11-24

Lafferty KD, Kuris AM (1993) Mass mortality of abalone Haliotis cracherodii in the California Channel Islands: tests of epidemiological hypotheses. Mar Ecol Prog Ser 96:239-248

Moore JD, Robbins TT, Friedman CS (2000) Withering syndrome in farmed red abalone, Haliotis rufescens: thermal induction and association with a gastrointestinal Rickettsiales-like procaryote. J Aquat Anim Health 12:26-34

Moore JD, Robbins TT, Hedrick RP, Friedman CS (2001) Transmission of the Rickettsiales-like procaryote "Candidatus Xenohaliotis californiensis" and its role in withering syndrome of California abalone Haliotis spp. J Shellfish Res 20:867-874

Moore JD, Finley CA, Robbins TT, Friedman CS (2002) Withering syndrome and restoration of Southern California abalone populations. Calif Coop Ocean Fish Invest Rep 43:112-117
Morales-Bojórquez E, Muciño-Díaz MO, Vélez-Barajas JA (2008) Analysis of the decline of the abalone fishery (Haliotis fulgens and $H$ corrugata) along the westcentral coast of the Baja California peninsula, Mexico. J Shellfish Res 27:865-870

Ponce-Díaz G, Serviere-Zaragoza E, Racotta IS, Reynoso-Granados T, Mazariegos-Villarreal A, Monsalvo-Spencer P, Lluch-Belda D (2004) Growth and tissue biochemical composition of Haliotis fulgens at elevated temperatures in Baja California under two dried brown algal diets. J Shellfish Res 23:1051-1057

Shaw BL, Battle HI (1957) The gross and microscopic anatomy of the digestive tract of the oyster, Crassostrea virginica (Gmelin). Can J Zool 35:325-347

Vilchis LI, Tegner MJ, Moore JD, Friedman CS, Riser KL, Robbins TT, Dayton PK (2005) Ocean warming effects on growth, reproduction, and survivorship of southern California abalone. Ecol Appl 15:469-480 